\title{
AGING AND SELF-DEVELOPMENT: PSYCHOLOGICAL PROBLEMS
}

\section{Maryna Smulson}

\section{INTRODUCTION}

Old age is a rather ambiguous period of life, which has not received enough attention in modern developmental psychology. It was not until the beginning of the 21 st century that society began to fight against ageism, that is, against prejudice against old age, rejection or neglect of the elderly. It is clear that this is due, first of all, to the apparent aging of humanity around the world, the steady increase in the number of older people in society.

For centuries, age distribution has looked like a pyramid, on top of which there are people that have reached old age. Now a sharp increase in life expectancy and a decline in fertility, especially in developed countries, have turned this pyramid into a mushroom with a massive hat. It is estimated that in 2060, the number of Americans over the age of 65 will double comparing to the current number - 92 million (20 percent). And nowadays, the most common diseases in the world are geriatric, namely, cardiovascular, cancer, diabetes and Alzheimer's disease.

Moreover, it is obvious that the boundary between adulthood and old age, and even between youth and old age is increasingly blurred and disappears, there is no specific moment of initiation from maturity to old age. In addition, today young people, and sometimes even the elderly, are actively involved in professional activities in many fields (economics, technology, culture, etc.). The retirement age is steadily rising, despite the protests of young people, sometimes quite active and rigid (France is a prime example). However, these protests are not related to the professional potential of the elderly, which almost no one questions, but to the struggles of young people for jobs. At the same time, employees often find it necessary to rely on the specialist's experience, which is related to his or her age and skills and wisdom acquired throughout life. On the other hand, such a situation certainly requires from an elderly professional constant selfdevelopment, professional and personal growth, which will block his / her lag from social and technological progress. This section is devoted to psychological problems of self-design and self-development.

\section{Specificity of self-development processes in old age}

There is a point of view that old age should not be treated as an age, but as an artificially constructed normative social project (design), that is, a set 
of conventional rules, laws, principles, norms, values, etc. This project defines not only the stereotyped attitude towards the elderly representatives of other generations, but also in many respects to the behaviour of the elderly themselves, their attitude towards themselves. The mechanisms of such construction, according to the sociologists M. Yeliutina and O. Smolkin include, first of all, an academic discourse (in particular, medical), which describes old age as a period of weakness, disability, survival, without defining the positive aspects of this period, secondly, the moral regulators that testify to the «elasticity» of the requirements for the treatment with elderly, and thirdly, the marker of intergenerational relations, highlighting the idea of present day old age as a model of one's own future old age. The following are some rather non-trivial mechanisms, such as the linguistic component, that is, the absence of positive semantic markers in terms related to aging, and, conversely, the presence of negative meanings (meaning, in general, opposition to the new-old) and the influence of the artistic discourse forming social expectations about the elderly. Finally, the modern «puerlistic» consciousness focuses public interest on the progress, change, «youth» of both people and ideas ${ }^{1,2}$.

From a psychological point of view, the most interesting point is the role of the elderly themselves in the design of such a project and the possibility of restructuring their attitude to themselves and their own problems of old age. In other words, it is about development and self-development in old age and their specificity.

Modern concepts of life-span development, that is, development that occurs throughout life, claim that any process of development is inherent in the internal dynamics of acquired and $\operatorname{lost}^{3,4,5,6,7}$. It is about life-long

1 Yeliutina M.E. (1999) Gerontologicheskoie napravleniie v strukture chelovecheskogo bytiia [Gerontological Direction in the Structure of Human Being] / M.E. Yeliutina. - Saratov : Izd. Sarat. gos. un-ta. - 139 p.

${ }^{2}$ Smolkin A.A. (2004) Sotsiokulturnaia dinamika otnosheniia k starosti [Sociocultural Dynamics of Attitude Towards Old Age]: dissertatsiia na soiskaniie uchenoi stepeni kandidata sociologicheskih nauk po specialnosti 22.00.04 : Sotsialnaia struktura, socialnyie instituty i processy [Social Structure, Social Institutions and Processes]/ A.A. Smolkin. - Saratov. - 144 p.

${ }^{3}$ Antsyferova L. I. (2006) Sposobnost lichnosti k preodoleniiu deformacii svoiego razvitiia [Person's Ability to Overcome Deformations of Their Development] / L. I. Antsyferova // Razvitiie lichnosti i problemy gerontopsihologii [Personality Development and Problems of Gerontopsychology]. - M.: Izd-vo „Institut psihologii RAN», - pp. 355-381.

${ }^{4}$ Baltes P. B. (2001) Vsevozrastnoj podhod v psihologii razvitiya: issledovanie dinamiki podemov i spadov na protyazhenii zhizni [An Age-Old Approach in Developmental Psychology: a Study of the Dynamics of Ups and Downs throughout Life] / P.B. Baltes // Psihologiya razvitiya : hrestomatiya [developmental psychology: anthology]. - SPb. : Piter. pp. 436-459.

${ }^{5}$ Maksymenko S.D. (2006) Geneza zdiisnennia osobystosti [Genesis of Special Features] / S. D. Maksymenko. - K. : Vydavnytstvo TOV «KMM». -240 p. 
development that never stops, even in death, which also determines a certain self-movement and self-development. The concept of non-linear development has emerged, according to which there is not only a lifelong potential growth, but there are downturns and plateaus, the amplification (enrichment) of certain functions and impoverishment of others, which also determines development. For example, it has been proven that intellectual development occurs throughout life and is multidimensional, but intellectual functioning changes - flowing operational-dynamic intelligence gradually transforms into crystallized domain-content. Operational-dynamic intelligence is associated with the basal organization of information processing and problem solving, and subject-content - with the functioning of operational-dynamic in the context of new knowledge and life situations ${ }^{8,9,10,11}$.

The task of development is significant in terms of the concept of continuous development. Development tasks include problems, demands and life situations that are generated by biological development, social expectations and human actions. These problems, as noted by experts, change in the course of life and provide direction, strength and fulfilment of development.

We associate development with changes in the mental model of the world, based on the concept of self-development (self-movement) of the personality of H. Kostiuk. Subjective self-development is seen as one in

\footnotetext{
${ }^{6}$ Smulson M.L. (2006) Smysl zhizni v mentalnoj modeli mira [Sense of Life in the Mental Model of the World] / M.L. Smulson // Psihologicheskiie problemy smysla zhizni i akme [Psychological Problems of Life Meaning and Acme]: materialy X simpoziuma / Pod red. G.A. Vaizer, E.E. Vahromova. - M. - pp. 28-29.

${ }^{7}$ Smulson M.L. (19-20 kvitnia 2010 roku) Kontseptsiia samorozvytku osobystosti H.S. Kostiuka i nagalni vyklyky siogodennia [The Concept of H.S. Kostiuk's Personality SelfDevelopment and Today's Urgent Challenges] / M.L. Smulson // Materialy II Vseukraiinskoho psihologichnoho konhresu, prisviachenogo 110 richnytsi vid dnia narodzhennia H.S. Kostiuka. Tom II. - K. : DP «Informatsiino-analitychne ahenstvo».

${ }^{8}$ Baltes P. B. (2001) Vsevozrastnoj podhod v psihologii razvitiya: issledovanie dinamiki podemov i spadov na protyazhenii zhizni [An Age-Old Approach in Developmental Psychology: a Study of the Dynamics of Ups and Downs throughout Life] / P.B. Baltes // Psihologiya razvitiya : hrestomatiya [developmental psychology: anthology]. - SPb. : Piter. pp. 436-459.

9 Smulson M.L. (2003) Psyholohiia rozvytku intelektu [Psychology of Intellectual Development] /M.L.Smulson - K.: Nora-druk. - 298 p.

${ }^{10}$ Smulson M.L. (2009) Intelekt i mentalni modeli svitu [Intelligence and Mental Models of the World] / M.L.Smulson // Naukovi zapysky. Seriia «Psihologiia i pedagogika». Tematichnyi vypusk «Suchasni doslidzhennia kognityvnoii psihologii» [Contemporary Studies in Cognitive Psychology] - Ostrog: Vid-vo Natsionalnogo universytetu «Ostrog». - Vip. 12. - pp. 38 - 49.

${ }^{11}$ Horn J.L. (1989) The Theory of Fluid and Crystailized Intelligence in Relations to Concepts of Cognitive Psychology and Aging in Adulthood / J.L. Horn // Aging and cognitive processes / Ed. by F.I.M. Craik, S. Trehuh. - New York : Plenu. - P. 76-112.
} 
which the subject sets his or her own goal of development, and uses various opportunities and potential to achieve it - both his own personal and that of the external environment. We associate self-development with the emerging of new formations; we interpret self-development as a change in the mental model of the world, or the system of mental models (mentality); and also as a new meaning; as a reinterpretation of personal experience. Selfdevelopment is determined by restructuring, amplification, reinterpretation, reconstruction of mental models of the world, restructuring of connections between them at all levels in the metamental model (i.e., the system model that defines personality) ${ }^{12,13,14}$.

However, is there any difference between the development of old age and development in other periods of life? We believe that the challenges of old age development are specific and, above all, related to the complex relationship between old age and the future.

The complex relationships of the old person with the past events influence their perception of the future events, moreover, even predetermine this perception. In this connection, experts refer to the philosophical characterization of Martin Heidegger's future (in Genesis and Time, 1923). According to Heidegger, the future not only comes to us, but rather we go to it with our expectations. Since these expectations are generated in the process of interpreting the past by us, the future should be understood as a continuation of the past. What is contemporary, then? The Continuous Process of Transformation of the Past into the Future» ${ }^{15}$.

Recall that Hoift et $\mathrm{al}^{16}$ distinguish between the immediate, near and distant future in the context of analysis of old age and aging.

The immediate future is a continuation of the present, and this connection is fundamental to the continuity of time. From the point of view of present time it is not perceived as an independent temporal level. The immediate future is reflected now, in particular, it is in line with the concept

${ }^{12}$ Kostiuk H.S. (1969) Princip razvitiia v psihologii [The Principle of Development in Psychology] / H.S. Kostiuk // Metodologicheskiie i teoreticheskiie problemy psihologii [Methodological and Theoretical Problems of Psychology]. - M.: Nauka. - pp. 118-152.

${ }^{13}$ Maksymenko S.D. (2006) Geneza zdiisnennia osobystosti [Genesis of Special Features] /

S. D. Maksymenko. - K. : Vydavnytstvo TOV «KMM». -240 p.

${ }^{14}$ Smulson M.L. (19-20 kvitnia 2010 roku) Kontseptsiia samorozvytku osobystosti H.S. Kostiuka i nagalni vyklyky siogodennia [The Concept of H.S. Kostiuk's Personality SelfDevelopment and Today's Urgent Challenges] / M.L. Smulson // Materialy II Vseukraiinskoho psihologichnoho konhresu, prisviachenogo 110 richnytsi vid dnia narodzhennia H.S. Kostiuka. Tom II. - K. : DP «Informatsiino-analitychne ahenstvo».

${ }^{15}$ Hoift G. (2003) Gerontopsihosomatika i vozrastnaia psihoterapiia [Gerontopsysomatics and Age-Related Psychotherapy] / G. Hojft, A. Kruze, G. Radebold. - M. : ACADEMIA (Izdatelskij Centr «Akademiia»). - 370 p., p.84.

${ }^{16}$ Ibid. 
of anticipatory reflection of P. Anokhin and M. Bernstein. The perception of the immediate future is the least painful for the elderly, it is so close and integrated with the present that the old person does not distinguish his perception and experience into a separate problem. This provides the continuity of time, even at a very old, advanced age, unless, of course, deep dementia is present.

The near future is interpreted as an area of the future that is linked to specific aspirations, plans, intentions, expectations, hopes, fears, etc. The near future is presented to us as an independent temporal level, and we are consciously preparing for it. The preparation and emotional experiences of expectations, hopes, fears, etc. separate the near future from the present, but the time span of the near future is not defined, it may be different - from days to years.

The attitude of the person to his/ her future is analysed according to his/ her time frames, confidence in the possibility of changing the situation, as well as the so-called density, for which there are large individual differences. Numerous plans and intentions testify to a constructive attitude towards one's future that mobilizes creativity. The other extreme, when there are almost no plans and intentions, when the future is perceived as somewhat amorphous, one that is not exposed, is presented as a frightening void which is a pathological relation to the future. It is shown that such perception of the future is characteristic of people (not only the elderly) who have lost their jobs for a long time, suffered other heavy losses and cannot act on their own.

It is crucial to make a conscious distinction between the immediate and the near future. As to the immediate future, one can recall Albert Einstein's famous ironic statement, «I never worry about the future, because it comes too fast». Therefore, the immediate future is sometimes figuratively called «the present that is ongoing.» Attempts to delay the «moment», to perceive the future as the present, which is ongoing, are also characteristic not only of the elderly, but also of certain neurotic states in many age categories. On the other hand, as Jonathan Swift very nicely put it: «The future never just happened. It was created».

Non-specific plans, which are expressed by the words «ever», are associated with the distant future. Attitudes towards the distant future may also be different. At any age, you may think that there is no «future», that the situation will not change, similar to a non-constructive attitude towards the near future. It is clear that such an opinion will not surprise the old man, but it is necessary to be sensitive to new stimuli both in the present and in the future.

The main tasks of development in old age are the successful overcoming of the crisis of old age, the victory over tanatophobia, dementia processes and more. It is shown that the optimum type of aging implies personal self- 
determination in old age in the unity of processes of self-development and self-realization ${ }^{17,18}$. Successful resolution of the crisis of old age implies personal development (self-development) in the direction of deepening of understanding of the world, wisdom, comprehension of the lived and experienced during life ${ }^{19,20,21,22}$. The lack of readiness for such changes in life position and values, for the transformation of the mental model, indicates an unprecedented crisis of meeting old age, and the increase in rigidity, in turn, leads to dementia. Therefore, the transformation (reinterpretation) of the mental model by a person who perceives his own old age as an unconditionally problematic, painful place should be a fundamental goal of working on the psychological support of the elderly.

However, the problems of development in old age are determined and solved mainly independently, they are fundamentally individualized, closely related to the attitude of a particular elderly person to all levels of the future described above, with an understanding of their place and significance in their own lives, taking into account their age, health condition, marital status, professional achievements, etc. Therefore, it can be stated that the mechanism of development in old age is «independent self-design» (although this phrase looks like a certain tautology). This means that selfdesign in old age, as a rule, has no analogues. It is unclear, "what life guidelines to choose», as it is mostly clear when it comes to self-design at other age levels, when development occurs in certain socially organized conditions (e.g., training, education, socially useful work). Attempts to

${ }^{17}$ Havrilina L. K. (2010) Krizisy vzrosloi zhizni: momenty rosta [Adult Life Crises: Moments of Growth] / L.K. Havrilina, V.M. Byzova. - Spb. : Rech [Speech]. - 221 p.

${ }^{18}$ Yermolaieva M.V. (2008) K voprosu o potentsialah razvitiia lichnosti v starosti [On the Issue of Personality Development Potentials in Old Age] / M.V. Yermolaieva, S.B. Priahina // Mir psihologii [World of psychology]. - №2. - pp. 244-255.

${ }^{19}$ Yermolaieva M.V. (2008) K voprosu o potentsialah razvitiia lichnosti v starosti [On the Issue of Personality Development Potentials in Old Age] / M.V. Yermolaieva, S.B. Priahina // Mir psihologii [World of psychology]. - №2. - pp. 244-255.

${ }^{20}$ Smulson M.L. (2006) Smysl zhizni v mentalnoj modeli mira [Sense of Life in the Mental Model of the World] / M.L. Smulson // Psihologicheskiie problemy smysla zhizni i akme [Psychological Problems of Life Meaning and Acme]: materialy X simpoziuma / Pod red. G.A. Vaizer, E.E. Vahromova. - M. - pp. 28-29.

${ }^{21}$ Smulson M.L. (19-20 kvitnia 2010 roku) Kontseptsiia samorozvytku osobystosti H.S. Kostiuka i nagalni vyklyky siogodennia [The Concept of H.S. Kostiuk's Personality SelfDevelopment and Today's Urgent Challenges] / M.L. Smulson // Materialy II Vseukraiinskoho psihologichnoho konhresu, prisviachenogo 110 richnytsi vid dnia narodzhennia H.S. Kostiuka. Tom II. - K. : DP «Informatsiino-analitychne ahenstvo»

${ }^{22}$ Rozuminnia ta interpretatsiia zhittievogo dosvidu yak chynnyk rozvytku osobystosti : monografiia [Understanding and Interpretation of Life Experience as a Factor of Personal Development : a Monograph] (2013) / za red. N.V.Chepelievoii. - Kirovograd : Imeks-LTD. $276 \mathrm{p}$. 
«return» from old age to younger age levels are not only impossible, but also harmful and risky (the life-threatening status of «young old» is known). On the other hand, to yield to old age, to surrender «at its mercy» and not to set the tasks of development is also extremely harmful, fraught with stagnation, «malignant» tanatophobia, dementia, etc. At the same time, defining the tasks of development implies understanding of the future as new, designed and created, rather than «current present».

Hence, there is the general specificity of development in old age, which fundamentally acts as self-development and requires special selfimprovement - from the intellectual to the physical - which we propose to call «the activity of self-development». At the same time, the transformations obtained are neither a direct product of another activity (as in a learning activity), nor a by-product (such as in work, cognitive, project, etc.). The regression of certain functions, their restructuring (not always amplified) also acts as a development. And as a result, the old person, constantly self-improving, adapts to the other self, receives a different structure of memory, attention, finally, general intelligence, and, most importantly, transformed and more adequate mental model of the world. Therefore, self-development activity is a separate, specifically organized activity, which we propose to consider as a leading activity in old age.

Development in old age, like any development, contributes to the emergence of new mental formations. Our theoretical and experimental studies show that such new mental formations include, first of all, the reflection of one's own problems brought by old age, the renewed (wise, integrative, restructured) mental model of the world, the realization of appropriate conscious choices, self-regulation and counteracting dementia, so called «overlapping» by their general intelligence, overcoming tanatophobic experiences. All these new mental formations, in turn, have the opposite positive effect on the development of the elderly. Thus, the studies conducted under our supervision have shown convincingly how much oldage development inhibits tanatophobic experiences, and what bright colours the life of an elderly person blossoms into as he directs the psychic energy that goes to fight the fear of death, to productive self-development activities $^{23,24}$.

${ }^{23}$ Berezina O. O. (2011) Doslidzhennia psihologichnyh osoblyvostei osib litniogo i pohylogo viku [Research of Psychological Characteristics of Elderly and Old People] / O. O. Berezina // Aktualni problemy psyhologii [Actual Problems of Psychology] : Zbirnyk naukovyh prats Instytutu psyhologii imeni H.S. Kostiuka NAPN Ukrainy / Za red. S. D. Maksymenka. - T. XIII. - Ch. I. - K. - pp. 49-58.

${ }^{24}$ Kovalenko-Kobylianska I.H. (2011) Spetsyfika nadannia psyhologichnoii dopomogy z urahuvanniam osoblyvostei pizniogo herontogenezu [The Specificity of Providing 
Another equally important goal of self-development in old age is to fight dementia. It is clear that dementia is a physiological process, and Alzheimer's disease is one of the worst manifestations here. Today, however, there is a psychologically attractive so-called existential view, according to which the psyche in old age is destroyed not only by an inverted process in the brain (in this case, according to M. Semkova, defeat of the patient and the one trying to help him should be recognized). This destruction, on the contrary, is acknowledged, at least in part, by the effects of gross, irrational psychological protections, and therefore it is hoped to influence the process in some way ${ }^{25}$.

Let us dwell in more detail on the relevant argumentation offered by the cited author. Yes, it is known that mental disorders in old age have clear, peculiar symptoms, which are not characteristic of other disorders of the psyche against the background of organic brain damage. Similar symptoms are memory impairment, acuteness, rapid mental fatigue. Depression can occur, especially if people are aware of the extent to which the disease has limited their ability.

However, the old people are characterized by such unusual for pure organic phenomena as anxiety, loss of orientation in time, a kind of delusional type of confidence that someone intentionally harms them or steals, threatens and so on. The reason for this is that the threat of extinction mobilizes the most powerful psychological protection that do not allow the thoughts of death to reach consciousness, even at the cost of psychic destruction.

In addition, according to some authors, old age with its loss (loved ones, health, working capacity, social status, etc.) should be considered as traumatic stress of extreme force and, accordingly, old age as post-traumatic stress. However, at the same time M. Siemkova describes features of the mental model of the subject, which contribute to the fundamental deterioration of mental health in old age. It was found out that all people under her investigation were strongly afraid of old age and death, had a developed sense of obligation, and perceived life as a rigorous obligation, were committed to professional achievement and / or family well-being, and at the same time, had little initiative. In addition, their emotional, close relationships were limited to the family, and any setbacks were seen as

Psychological Assistance, Taking into Account the Features of Late Gerontogenesis] [Elektronnyi resurs] / I.G. Kovalenko-Kobylianska // Tehnologii rozvytku intelektu [Intelligence Development Technologies]. T. 1, № 2 Retrieved from www.psytir.org.ua/ index.php./technology_intellect_develop/ article/view/43.

${ }_{25}$ Siemkova M.P. (2008) Neprozhitaia starost [Unwell old age] [Elektronnij resurs] / M.P.Siemkova // Retrieved from www.samlib/ru/s/semkowa_m_p /neprozhitayastarostx. Shtml 
catastrophes and needed support. For such individuals, the weak point is the conflict in the area of freedom / dependence and autonomy / subordination. Interestingly, these traits often lead to neuroses and depression of younger people. Therefore, as we can see, according to the approach described above, we can make a certain prediction of the old man's predisposition to dementia.

\section{Intellect and Wisdom in Old Age}

We have already noted that intellectual processes, in particular, flowing and crystallized intelligence undergo significant changes in old age. There are also certain special cognitive (intellectual) signs that indicate dementia potential. Cognitive impairment common to dementia affects more than one area of cognitive functioning. Alistair Burns and Tony Hope note in the book, «Old Age Psychiatry» (Old Age Psychiatry, 2003) that memory and at least one of such cognitive functions as speech and constructive ability, thinking, reasoning are most commonly impaired.

As to memory, the most striking aspects of dementia are the deliberate reproduction (remembering) of new information and prospective memory (remembering that something needs to be done in response to a specific hint: such as, to turn off the light before leaving home). Memory of recent events is affected by dementia more than distant ones ${ }^{26,27}$. People with dementia have impaired discursive, that is, narrative, abilities ${ }^{28}$.

Neuropsychological studies of normal aging, performed at the school of O. Luria, indicate that the leading age-related symptom of normal aging is a slowdown in activity (latency), especially at the stage of its initiation ${ }^{29,30}$. The latter is most evident when retrieving information from storage systems. Later, the possibilities of simultaneous multichannel concurrent performance

${ }^{26}$ Huppert F.A. (1994) Memory Function in Dementia and Normal Aging - dimension or dichotomy? / F.A.Huppert // Dementia and Normal Aging / Ed. by F.A. Huppert, C. Brayne, D.W. O'Conner. - Cambridge : Cambridge University Press. - P. 291-330.

${ }^{27}$ Huppert F.A. (1994) What Is the Relationship between Dementia and Normal Aging? / F.A. Huppert, C. Brayne // Dementia and normal ageing / Ed. by F.A. Huppert, C. Brayne, D.W. O'Conner. - Cambridge : Cambridge University Press. - P. 3-11.

28 Kempler D. (1994) Language in Dementia and Normal Ageing/ D. Kempler, E.M. Zelinski // Dementia and normal ageing / Ed. by F.A. Huppert, C. Brayne, D.W. O’Conner. - Cambridge : Cambridge University Press. - P. 331-365.

${ }^{29}$ Korsakova N. K. (1996) Neiropsihologiia pozdnego vozrasta: obosnovaniie kontseptsii i prikladnyie aspekty [Late Age Neuropsychology: Concept and Applied Aspects Ground] // Vestn. Mosk. un-ta. - Ser. 14. Psihologiia. - № 2. - pp. 32-37.

30 Roshchina I.F. (2015) Issledovanie normalnogo i patologicheskogo stareniia (neiropsihologicheskii podhod) // Medicinskaia psihologiia v Rossii [The Study of Normal and Pathological Aging (Neuropsychological Approach) // Medical Psychology in Russia]: elektron. nauch. zhurn. - N 2(31) [Elektronnyj resurs]. - Retrieved from: http://mprj.ru 
of various actions, i.e. difficulties of switching and distribution of attention, come to a limit. There is a limitation in the flow of memory, reducing its resistance to distractions. These cognitive limitations are thought to be related to the functional deficits of the first brain block, as the overall background components of activity change: the energy supply of mental activity decreases, the inhibition processes predominate.

The second component of normal aging is due to limitations in the processing of spatial information characteristics. Relevant data indicate a decrease in the right hemisphere's involvement in cognitive processes. Again, problems arise with parallel multichannel processing of information, since the time-integrated function is based on the principle of simultaneity inherent in the right hemisphere ${ }^{31}$.

The school of $\mathrm{O}$. Luriia basically distinguishes three variants of normal aging. The first is based on a decrease in the level of energy support for the activity already discussed above. Its characteristic manifestations are a rather long latency when engaging in the activity, a relatively small period of its effective implementation, followed by exhaustion and incompleteness of actions, as well as one-channel processing of information. The prerequisites for preserved mental functioning are the preservation of criticality, the regulative role of speech, the existence of strategies that ensure the distribution of activity in time and internal space. Therefore, in this variant of normal aging self-design should be aimed directly at amplification - the development of these preconditions. Let us highlight again that this is the persistence of criticality, the regulatory role of conceptual thinking, the development of specific strategies for distributed activity.

The second variant of normal aging, as noted above, is related to the lack of simultaneity in the processing of first-party information in the visualspatial sphere. This variant of aging can be considered as the most favourable, especially with the purposeful use of the strategy of grinding the procedures of the problem solution, «transfer of actions to the level of the extensive, step-by-step, consistent, controlled execution $»^{32}$, i.e. performing of actions without so-called automatisms. Special work on self-design and

31 Roshchina I.F. (2015) Issledovanie normalnogo i patologicheskogo stareniia (neiropsihologicheskii podhod) // Medicinskaia psihologiia v Rossii [The Study of Normal and Pathological Aging (Neuropsychological Approach) // Medical Psychology in Russia]: elektron. nauch. zhurn. - N 2(31) [Elektronnyj resurs]. - Retrieved from: http://mprj.ru

32 Roshchina I.F. (2015) Issledovanie normalnogo i patologicheskogo stareniia (neiropsihologicheskii podhod) // Medicinskaia psihologiia v Rossii [The Study of Normal and Pathological Aging (Neuropsychological Approach) // Medical Psychology in Russia]: elektron. nauch. zhurn. - N 2(31) [Elektronnyj resurs]. - Retrieved from: http://mprj.ru 
self-development towards mastering such a strategy can have a positive effect on the lack of simultaneity.

However, it is known that abrupt changes in the space of life (in the broad sense of the word) can lead to decompensation, such as a change of residence or linguistic environment. Therefore, preparation for such a change requires special work on appropriate self-design and further selfdevelopment, as well as general amplification requests for development in all areas where there is potential for decompensation.

The third variant of aging is characterized by a decrease in the arbitrary regulation of activity in the aspect of predicting the result and building adequate programs. This refers to impulsive decision-making, inadequate assessment of one's own capabilities, which, while maintaining cognitive criticality, can lead to decompensation, failure experiences, etc.

It is obvious that adequate design and self-design of the activity outcome, which underpins its prognosis, are required in this case.

If it has been a matter of normal aging variants so far, which, on the assumption of self-design and self-development task awareness, could be compensated, then the fourth variant of aging is dangerous in terms of decompensation. It combines two dangerous factors: energy support for the activity and its arbitrary regulation. In this case the insufficient spontaneity, sphere of interest narrowing, emotional monotony and increased forgetfulness occur. Somatic diseases and deprivation of communication contribute to the transformation of this variant of aging into dementia ${ }^{33}$.

Consideration should also be given to the specificity of the amplification of mental development at this age. The amplification of mental development is generally regarded as the maximum use of opportunities of every age for healthy mental development. O. V. Zaporozhets opposed the amplification to the artificial acceleration of the child development, which is accompanied by the simplification of development, that is, its stripping and impoverishing ${ }^{34}$. Currently, the concept of amplification has been the most developed for the preschool childhood, but we believe that it can be used for all ages including the elderly one. Moreover, if «co-operation» of the acceleration and amplification processes can be assumed for some other aging periods, the acceleration of the elderly mental development is impossible in the conditions of limited life resource.

Therefore, we can only speak of certain amplification, enrichment of mental development in old age, such as training and replacement of

${ }^{33}$ Ibid.

${ }^{34}$ Zaporozhets A.V. (1986) Izbrannyie psihologicheskiie trudy [Selected Psychological Works] / A.V. Zaporozhets - V dvuh tomah. - T.1. Psihicheskoie razvitiie rebenka [Child's Mental Development]. - M.: Pedagogika. -320 p. 
weakened mental functions (such as memory), compensation and «overlapping» them with other functions of general intelligence. Conscious self-development of personality in old age involves independent decisionmaking about the directions of such amplification based on understanding one's own involutional deficits or regression. It follows therefrom that selfdevelopment and self-design in old age do not exclude the understanding of the age deficiency existence. It famously accompanies normal aging, and its consideration and awareness largely determine the specific features of intellectual problems in old age.

As noted above, one of the components of cognitive aging is the change in the vector of brain hemisphere activity toward the dominance of the left hemisphere. In this aspect, neuropsychological studies are convincingly confirmed by psychological researches of conceptual thinking in the elderly, conducted under the guidance of M. O. Kholodnaia ${ }^{35}$.

In her opinion, they are precisely the later stages of ontogenesis when certain effects are most clearly manifested, which generally characterize the mechanisms of functioning intelligence. This is, in particular, the heterogeneous and compensatory nature of intellectual activity. Experimental studies conducted under her leadership confirm the major results, according to which a discernable decrease in old age indicates fluid intelligence. Indicators of crystallized intelligence, in particular verballogical function, are the most retained.

A comparative study of the college students' and the elderly's intelligence shows, in particular, that the latter have the same indicators as the students have at the factor of «verbal understanding» (crystallized intelligence) and significantly lower indicators at the factors of «spatial organization» and «memory / attention concentration» (Fluid intelligence). At the same time, the study of cognitive styles revealed that the older people are much more dependent and rigid than the young people, that is, demonstrate the rigidity of the intellectual system. This suggests that in the context of increasing involutional deficits, conceptual thinking unmediatedly regulates the intellectual activity of an old man, acting as a compensatory resource $^{36}$.

${ }^{35}$ Kholodnaia M.A. (2012) Psiholohiia poniatiinogo myshleniia: Ot kontseptualnyh struktur k poniatiinym sposobnostiam [The Psychology of Conceptual Thinking: From Conceptual Structures to Conceptual Abilities] / M.A.Kholodnaia - M.: Izd-vo «Institut psihologii RAN». $288 \mathrm{p}$.

${ }^{36}$ Kholodnaia M.A. (2012) Psiholohiia poniatiinogo myshleniia: Ot kontseptualnyh struktur k poniatiinym sposobnostiam [The Psychology of Conceptual Thinking: From Conceptual Structures to Conceptual Abilities] / M.A.Kholodnaia - M.: Izd-vo «Institut psihologii RAN». $288 \mathrm{p}$. 
Therefore, in the neuropsychological and psychological studies analyzed above, the compensatory capacity and functional retention of the left hemisphere, that is, conceptual thinking, are considered as a protector factor against the feasible development of dementia processes in normal aging. Conceptual thinking activates sound defense mechanisms, enabling the mental model's transformation. On the other hand, training cognitive and metacognitive components of intelligence is of fundamental importance. Due to the fact, E. Goldberg offers some indirect approaches to the development of flexibility and transformation of the mental model through the influence on metacognitive functions, i.e. on the intellect (it is not about a certain mental skill, but about organizing them all). These include the systematic creation of tools, the creation of images of the future, language as metacognition (providing the means of models' creation, and management functions - the means of models' manipulation and carrying out operations on them), as well as goal-setting and self-awareness ${ }^{37,38}$.

Under this approach, it is almost irrelevant what old people remember. What is important, on the contrary, is how they conceive, understand, interpret, and reinterpret their own experience, both old and new, fresh. Flexible mental models are considered to be such interpretative schemes. They are formed over a lifetime and are the basis of pattern recognition (it is the ability to recognize a new object or new problem as an element of a familiar class of objects or problems).

According to E. Goldberg, they are the basis of the wisdom of the elderly, which he defines as «the ability to combine the new with the old, to use the old experience to solve a new problem ${ }^{39}$. Wisdom is the highest level of competence, that is, the special ability to recognize similar elements between new and previously solved tasks. The latter presupposes that a competent (wise) person has a large set of mental images, each of which captures the essence of a wide range of specific situations and the most effective actions related to these situations. Nonetheless, the source of wisdom is not only the individual's own wisdom. The origin of wisdom (as well as mentality) is a culture that represents the collective wisdom of society, as well as the wisdom of class, species, and group. Only after

${ }^{37}$ Goldberg E. (2003) Upravliaiushchii mozg: lobnyie doli, liderstvo i civilizatsiia [The Governing Brain: Frontal Lobes, Leadership and Civilization] / E. Goldberg. - M. : Smysl. $335 \mathrm{p}$.

${ }^{38}$ Goldberg E. (2007) Paradoks mudrosti [The Paradox of Wisdom] / E.Goldberg. - M. : Pokolenie. $-384 \mathrm{p}$.

${ }^{39}$ Goldberg E. (2007) Paradoks mudrosti [The Paradox of Wisdom] / E.Goldberg. - M. : Pokolenie. -384 p. 
coming to grips with the above types of wisdom, one may talk of the individual's wisdom ${ }^{40}$.

Competence and wisdom, according to E. Goldberg, is not only an advanced ability to penetrate into the essence of things, but also an understanding of what action must be taken to change them. Therefore, both wisdom and competence are valued for their prescriptive capacity.

The majority of people associate wisdom with old age. J. Heckhausen, R.Dixon, and P. Bolts made a survey concerning the properties the experiment participants acquire at different ages. Virtually everyone reckoned that wisdom became the dominant attribute of people after they were fifty years old. In terms of desirability, wisdom was also among the most desirable traits. M. Perlmater and colleagues have also found that most people consider wisdom a desirable property ${ }^{41}$. It turns out, as E. Goldberg rightly points out, «if people believe that wisdom is the reward of old age, and they also see wisdom as one of their most desirable traits, then they should also believe that aging has its benefits, its positive side and its unique and valuable assets» ${ }^{42}$.

\section{CONCLUSIONS}

The basic directions of normal aging, the psychological support of which is connected with the amplified development of certain specific intellectual and activity components in old age have been shown above. Selfdevelopment and self-design should be aimed at the overall reinterpretation of the mental model in old age, which is required to achieve mental wellbeing at this age. In doing so, one should take into account the peculiarities of the subject's mental model, which lead to a fundamental mental health deterioration in old age. It is obvious for the elderly that the mental development acceleration tends to be unacceptable and impossible in view of limited life resources. Therefore, we may only speak of certain amplification, enrichment of mental development in old age. Conscious selfdesign and self-development of an individual in old age implies independent decision-making concerning the directions of such amplification based on understanding their own involutional deficits. This requires relevant intellectual support at the level of conceptual thinking, that is, reflected intellectual actions.

\footnotetext{
${ }^{40}$ Ibid.

${ }^{41}$ Ibid.

${ }^{42}$ Goldberg E. (2007) Paradoks mudrosti [The Paradox of Wisdom] / E.Goldberg. - M. : Pokolenie. -384 p.
} 


\section{SUMMARY}

Old age is a specific age period, sometimes regarded as a «social project». The role, played by the elderly in designing such a project as well as restructuring their attitude to themselves and their own old age problems, is crucial. The main tasks of development in old age are the successful overcoming of an old age crisis, conquering tanatophobia, dementia processes and more. Development in old age acts as self-development. Selfdevelopment activity (work) is a particular, specifically organized activity, which we consider as a leading activity in old age.

It may well be argued that the updated (wise, integrative, restructured) mental model of the world, reflection of one's own problems brought by old age, realization of relevant conscious choices, self-regulation and opposition to demental processes, the so-called «overlapping» by their general intelligence, overcoming tanatophobic experiences should be distinguished among the newly formed structures. The key point in the fight against dementia is, first, the mental model's transformation, and second, the cognitive and metacognitive intelligence components training.

Successful tackling old age crisis implies personal development (selfdevelopment) in the direction of advanced understanding of the world, wisdom, sense of life and survivorship in the course of a lifetime. The lack of readiness for such changes in view and values of life, the transformation of the mental model bears testimony to an unconquerable old age related crisis while the increase in rigidity, in its turn, leads to dementia. The leading psychological conditions for the transformation of mental models include the process link with intellectual changes and enrichment of intelligence, with the reflection and the interpretative (narrative) potential of the subject, on the one hand, and the subject's readiness for self-development, on the other.

\section{REFERENCES}

1. Antsyferova L. I. (2006) Sposobnost lichnosti k preodoleniiu deformacii svoiego razvitiia [Person's Ability to Overcome Deformations of Their Development] / L. I. Antsyferova // Razvitiie lichnosti i problemy gerontopsihologii [Personality Development and Problems of Gerontopsychology]. - M.: Izd-vo „Institut psihologii RAN», - pp. 355381. [in Russian]

2. Baltes P. B. (2001) Vsevozrastnoj podhod v psihologii razvitiya: issledovanie dinamiki podemov i spadov na protyazhenii zhizni [An AgeOld Approach in Developmental Psychology: a Study of the Dynamics of Ups and Downs throughout Life] / P.B. Baltes // Psihologiya razvitiya : hrestomatiya [developmental psychology: anthology]. - SPb. : Piter. pp. 436-459. [in Russian]

3. Berezina O. O. (2011) Doslidzhennia psihologichnyh osoblyvostei osib litniogo i pohylogo viku [Research of Psychological Characteristics of 
Elderly and Old People] / O. O. Berezina // Aktualni problemy psyhologii [Actual Problems of Psychology] : Zbirnyk naukovyh prats Instytutu psyhologii imeni H.S. Kostiuka NAPN Ukrainy / $\mathrm{Za}$ red. S. D. Maksymenka. - T. XIII. - Ch. I. - K. - pp. 49-58. [in Ukrainian]

4. Havrilina L. K. (2010) Krizisy vzrosloi zhizni: momenty rosta [Adult Life Crises: Moments of Growth] / L.K. Havrilina, V.M. Byzova. - Spb. : Rech [Speech]. - 221 p. [in Russian]

5. Goldberg E. (2003) Upravliaiushchii mozg: lobnyie doli, liderstvo i civilizatsiia [The Governing Brain: Frontal Lobes, Leadership and Civilization] / E. Goldberg. - M. : Smysl. - 335 p. [in Russian]

6. Goldberg E. (2007) Paradoks mudrosti [The Paradox of Wisdom] / E. Goldberg. - M. : Pokolenie. - 384 p. [in Russian]

7. Hoift G. (2003) Gerontopsihosomatika i vozrastnaia psihoterapiia [Gerontopsysomatics and Age-Related Psychotherapy] / G. Hojft, A. Kruze, G. Radebold. - M. : ACADEMIA (Izdatelskij Centr «Akademiia»). - 370 p. [in Russian]

8. Horn J.L. (1989) The Theory of Fluid and Crystailized Intelligence in Relations to Concepts of Cognitive Psychology and Aging in Adulthood / J.L. Horn // Aging and cognitive processes / Ed. by F.I.M. Craik, S. Trehuh. - New York : Plenu. - P. 76-112. [in English]

9. Huppert F.A. (1994) Memory Function in Dementia and Normal Aging - dimension or dichotomy? / F.A.Huppert // Dementia and Normal Aging / Ed. by F.A. Huppert, C. Brayne, D.W. O'Conner. - Cambridge : Cambridge University Press. - P. 291-330. [in English]

10. Huppert F.A. (1994) What Is the Relationship between Dementia and Normal Aging? / F.A. Huppert, C. Brayne // Dementia and normal ageing / Ed. by F.A. Huppert, C. Brayne, D.W. O’Conner. - Cambridge : Cambridge University Press. - P. 3-11. [in English]

11. Kempler D. (1994) Language in Dementia and Normal Ageing/ D. Kempler, E.M. Zelinski // Dementia and normal ageing / Ed. by F.A. Huppert, C. Brayne, D.W. O'Conner. - Cambridge : Cambridge University Press. - P. 331-365. [in English]

12. Kholodnaia M.A. (2012) Psiholohiia poniatiinogo myshleniia: Ot kontseptualnyh struktur k poniatiinym sposobnostiam [The Psychology of Conceptual Thinking: From Conceptual Structures to Conceptual Abilities] / M.A. Kholodnaia - M.: Izd-vo «Institut psihologii RAN». - 288 p. [in Russian]

13. Korsakova N. K. (1996) Neiropsihologiia pozdnego vozrasta: obosnovaniie kontseptsii i prikladnyie aspekty [Late Age Neuropsychology: Concept and Applied Aspects Ground] // Vestn. Mosk. un-ta. - Ser. 14. Psihologiia. - № 2. - pp. 32-37. [in Russian]

14. Korsakova N.K. (1997) Neirogerontopsihologiia: razvitie idei shkoly A.R. Luriia // I Mezhdunarodnaia konferenciia pamiati A.R. Lurii 
[Neurogerontopsychology: the Development of A.R. Luriia's School Ideas // I International Conference in Memory of A.R. Luriia]. Tezisy dokladov / pod red. E.D. Homskoi. - M.: MGU; RAN; RAO. - pp. 50-51.[in Russian]

15. Kostiuk H.S. (1969) Princip razvitiia v psihologii [The Principle of Development in Psychology] / H.S. Kostiuk // Metodologicheskiie i teoreticheskiie problemy psihologii [Methodological and Theoretical Problems of Psychology]. - M.: Nauka. - pp. 118-152. [in Russian]

16. Kovalenko-Kobylianska I.H. (2011) Spetsyfika nadannia psyhologichnoii dopomogy $\mathrm{z}$ urahuvanniam osoblyvostei pizniogo herontogenezu [The Specificity of Providing Psychological Assistance, Taking into Account the Features of Late Gerontogenesis] [Elektronnyi resurs] / I.G. Kovalenko-Kobylianska // Tehnologii rozvytku intelektu [Intelligence Development Technologies]. T. 1, № 2 Retrieved from www.psytir.org.ua/index.php./technology_intellect_develop/article/view/43. [in Ukrainian]

17. Maksymenko S.D. (2006) Geneza zdiisnennia osobystosti [Genesis of Special Features] / S. D. Maksymenko. - K. : Vydavnytstvo TOV «KMM». -240 p. [in Ukrainian]

18. Psihiatriia pozdnego vozrasta [Psychiatry of Late Age] (2003) / Pod red. Robina Dzhekobi, Katrin Oppengaimer. - K. : Sfera. - T.2. - 507 p. [in Russian]

19. Roshchina I.F. (2015) Issledovanie normalnogo i patologicheskogo stareniia (neiropsihologicheskii podhod) // Medicinskaia psihologiia v Rossii [The Study of Normal and Pathological Aging (Neuropsychological Approach) // Medical Psychology in Russia]: elektron. nauch. zhurn. N 2(31) [Elektronnyj resurs]. - Retrieved from: http://mprj.ru [in Russian]

20. Rozuminnia ta interpretatsiia zhittievogo dosvidu yak chynnyk rozvytku osobystosti : monografiia [Understanding and Interpretation of Life Experience as a Factor of Personal Development : a Monograph] (2013) / za red. N.V.Chepelievoii. - Kirovograd : Imeks-LTD. - 276 p. [in Ukrainian]

21. Siemkova M.P. (2008) Neprozhitaia starost [Unwell old age] [Elektronnij resurs] / M.P.Siemkova // Retrieved from www.samlib/ru/s/ semkowa_m_p /neprozhitayastarostx. Shtml [in Russian]

22. Smolkin A.A. (2004) Sotsiokulturnaia dinamika otnosheniia k starosti [Sociocultural Dynamics of Attitude Towards Old Age]: dissertatsiia na soiskaniie uchenoi stepeni kandidata sociologicheskih nauk po specialnosti 22.00 .04 : Sotsialnaia struktura, socialnyie instituty i processy [Social Structure, Social Institutions and Processes]/ A.A. Smolkin. - Saratov. 144 p. [in Russian]

23. Smulson M.L. (19-20 kvitnia 2010 roku) Kontseptsiia samorozvytku osobystosti H.S. Kostiuka i nagalni vyklyky siogodennia [The Concept of H.S. Kostiuk's Personality Self-Development and Today's Urgent Challenges] / M.L. Smulson // Materialy II Vseukraiinskoho psihologichnoho konhresu, prisviachenogo 110 richnytsi vid dnia 
narodzhennia H.S. Kostiuka. Tom II. - K. : DP «Informatsiino-analitychne ahenstvo». [in Ukrainian]

24. Smulson M.L. (2003) Psyholohiia rozvytku intelektu [Psychology of Intellectual Development] /M.L.Smulson - K.: Nora-druk. - 298 p. [in Ukrainian]

25. Smulson M.L. (2006) Smysl zhizni v mentalnoj modeli mira [Sense of Life in the Mental Model of the World] / M.L. Smulson // Psihologicheskiie problemy smysla zhizni i akme [Psychological Problems of Life Meaning and Acme]: materialy $X$ simpoziuma / Pod red. G.A. Vaizer, E.E. Vahromova. - M. - pp. 28-29. [in Russian]

26. Smulson M.L. (2009) Intelekt i mentalni modeli svitu [Intelligence and Mental Models of the World] / M.L.Smulson // Naukovi zapysky. Seriia «Psihologiia i pedagogika». Tematichnyi vypusk «Suchasni doslidzhennia kognityvnoii psihologii» [Contemporary Studies in Cognitive Psychology] Ostrog: Vid-vo Natsionalnogo universytetu «Ostrog». - Vip.12. pp. 38 - 49. [in Ukrainian]

27. Tsvetkova L.S. (2008) Mozg i intellekt: narusheniie i vosstanovleniie intellektualnoi deyiatelnosti [Brain and Intelligence: Disruption and Restoration of Intellectual Activity] / L.S. Tsvetkova. - M. : Izdatelstvo Moskovskogo psihologo-sotsialnogo instituta. - 424 p. [in Russian]

28. Yeliutina M.E. (1999) Gerontologicheskoie napravleniie v strukture chelovecheskogo bytiia [Gerontological Direction in the Structure of Human Being] / M.E. Yeliutina. - Saratov : Izd. Sarat. gos. un-ta. - 139 p. [in Russian]

29. Yermolaieva M.V. (2008) K voprosu o potentsialah razvitiia lichnosti v starosti [On the Issue of Personality Development Potentials in Old Age] / M.V. Yermolaieva, S.B. Priahina // Mir psihologii [World of psychology]. № 2. - pp. 244-255. [in Russian]

30.Zaporozhets A.V. (1986) Izbrannyie psihologicheskiie trudy [Selected Psychological Works] / A.V. Zaporozhets - V dvuh tomah. - T.1. Psihicheskoie razvitiie rebenka [Child's Mental Development]. - M.: Pedagogika. - 320 p. [in Russian]

\section{Information about the author: Smulson Maryna,}

Real member of the National Academy of Pedagogical Sciences of Ukraine, Professor, Doctor of Psychological Science, Head of Department of Modern Information Technologies of Education, G.S. Kostiuk Institute of Psychology of the National Academy of

Pedagogical Sciences of Ukraine, 2 Pankivska str., Kyiv, Ukraine, 01033 ORCID ID: orcid.org/ /0000-0002-9563-3390 smulson@ukr.net 